\title{
Nowcasting Jumlah Penumpang Kereta Api di Indonesia Menggunakan Indeks Google Trends
}

(Nowcasting The Number of Train Passengers in Indonesia Using Google Trends Index)

\author{
Parma Dwi Widy Oktama \\ Badan Pusat Statistik Republik Indonesia \\ Jalan Dr. Sutomo 6-8, Jakarta Pusat, Indonesia \\ E-mail: prm.oktama@gmail.com
}

\begin{abstract}
ABSTRAK
Jumlah penumpang kereta api merupakan salah satu indikator strategis di sektor transportasi. Rilis data yang dilakukan BPS dengan jeda waktu tiga puluh hari sejak berakhirnya bulan amatan, menjadikan kondisi indikator ini tidak diketahui secara real time. Dengan trend penggunaan mesin pencari di internet yang semakin masif dewasa ini, penelitian ini bertujuan untuk mengkaji kemungkinan pemanfaatan Indeks Google Trends (GT) untuk melakukan nowcasting sehingga didapatkan kondisi indikator lebih awal. Hasil penelitian menunjukkan bahwa indeks GT dan official statistics yang dirilis BPS memiliki korelasi kuat dan kesamaan pola pergerakan dari waktu ke waktu. Penerapan Indeks GT ke dalam pemodelan runtun waktu menggunakan time series regression dan SARIMAX mampu mendekati nilai aktual variabel respon dengan cukup baik. Selain itu terbukti bahwa pemanfaatan indeks GT dapat meningkatkan akurasi peramalan model. Dengan time series regression, hasil nowcasting jumlah penumpang kereta api di Indonesia pada bulan Agustus 2021 adalah sebesar 9,03 juta orang.
\end{abstract}

Kata kunci: nowcasting, google trends, penumpang kereta api, regresi time series, SARIMAX

\section{ABSTRACT}

The number of train passengers is one of strategic indicators especially in transport sector. Since the official number's released by BPS has a thirty-days lag since the end of observed month, makes the condition of this indicators could not be known real time. By the rapid increase of search engine's utilization nowadays, this paper aimed to explores the possibility of applying google trends index in nowcasting to know earlier the condition of the indicator. The results shows that the google trend index and the official statistics released by BPS has a strong correlation and made the same patterns over the time. The application of GT Index to the econometric model using time series regression and SARIMAX could approach the actual values of dependent variable remarkably good. Besides, the use of google trends index could increase the model accuracy in forecasting needs. The nowcasting results with time series regression shows the number of train passengers in Indonesia on August 2021 is around 9.03 million people.

Keywords: nowcasting, google trends, train passengers, time series regression, SARIMAX

\section{PENDAHULUAN}

Penggunaan internet dalam menunjang kehidupan manusia meningkat pesat dewasa ini. Internet telah berkembang menjadi bagian yang tak terpisahkan dan mendisrupsi hampir di seluruh sektor. Pada tahun 2020, penetrasi pengguna internet di Indonesia mencapai 73,7\% atau sebesar 196,7 juta jiwa (APJII, 2020). Seiring dengan besarnya jumlah penetrasi pengguna internet, hal ini memiliki implikasi besarnya pemanfaatan mesin pencari di internet dalam mendukung aktivitas sehari-hari. Salah satu mesin pencari yang cukup banyak digunakan adalah Google Search. Google Search melakukan pencarian yang relevan dengan kata kunci yang diinput oleh pengguna. Intensitas pencarian dengan kata kunci ini, menghasilkan suatu data dengan volume besar (big data) yang kemudian tersimpan dalam database pencarian Google. Sejak tahun 2009, Google mulai mendiseminasikan intensitas pencarian berdasarkan volume kata kunci dengan Google Trends Index (Indeks GT). Indeks GT menyajikan suatu indeks yang telah ternomalisasi dalam rentang angka 1-100 dan tersedia dalam berbagai periode laporan mulai indeks harian hingga tahunan.

Informasi yang digambarkan dengan indeks GT diprediksi memiliki korelasi dengan fenomena atau trend aktivitas masa kini yang sedang berlangsung di masyarakat. Choi and Varian (2012) menyatakan bahwa data Google Trends menjadi cabang baru dari ekonometrika yang saat ini banyak digunakan dalam melakukan melakukan prediksi masa kini terhadap kondisi pasar tenaga kerja, trend konsumsi publik, retail penjualan mobilitas penduduk (travel) hingga inflasi. Suatu prediksi terhadap kejadian/informasi masa kini lazim disebut nowcasting. Nowcasting merupakan prediksi masa depan yang memiliki jarak periode waktu sangat dekat 
(Ayuningtyas, 2020). Teknik nowcasting telah banyak digunakan untuk memantau berbagai indikator ekonomi suatu wilayah secara real time.

Banyak indikator yang digunakan untuk menggambarkan kondisi ekonomi Indonesia, akan tetapi indikator-indikator tersebut mayoritas dirilis oleh Badan Pusat Statistik (BPS) dengan jeda (lag) waktu. Salah satu indikator strategis yang memiliki efek domino terhadap sektor perekonomian lain adalah jumlah penumpang kereta api. Indikator ini menjadi indikator penting untuk sektor transportasi terutama pada angkutan darat. Menurut data BPS, pada triwulan satu tahun 2021, angkutan darat mencatatkan total share terhadap PDB hingga 2,49\% dan triwulan dua sebesar 2,40\%. Pada triwulan tiga, sektor ini diprediksikan banyak pakar menjadi sektor yang banyak terdampak oleh kebijakan pemberlakuan pembatasan kegiatan masyarakat (PPKM) darurat dan ketat selama hampir dua bulan yakni pada Juli dan Agustus 2021. Sementara itu, secara proses bisnis, indikator ini dihasilkan BPS dengan lag waktu rilis kurang lebih tiga puluh (30) hari. Dengan terdapatnya jeda terhadap waktu rilis maka kondisi sektor tersebut pada waktu terkini tidak diketahui.

Dengan menggabungkan fenomena bahwa pola konsumsi masyarakat, termasuk penumpang kereta api, yang telah banyak bergeser ke pola konsumsi digital karena penetrasi masif internet dewasa ini, dan terdapatnya permasalahan jeda waktu terhadap rilis data official statistics, peneliti mencoba mengkaji kemungkinan pemanfaatan indeks mesin pencari google (google trends index) untuk mengetahui pola pergerakan indikator official statistics terkait lebih awal. Selanjutnya, penelitian ini juga bertujuan untuk memanfaatkan Indeks Google Trends dalam melakukan nowcasting terhadap jumlah penumpang kereta api pada kondisi waktu terkini, sehingga kondisi perekonomian lain yang menyertainya juga dapat terdeteksi lebih dini.

Choi dan Varian (2012) menyatakan bahwa saat ini telah banyak penelitian yang menganalisis peran Google Trends dalam melakukan prediksi masa kini/nowcasting terhadap berbagai sektor ekonomi. Sejalan dengan pendapat tersebut, Mitra et,al (2017) pernah melakukan kajian mengenai penggunaan Google Trends dalam meramalkan penjualan real estate di India. Dalam penelitianya, disimpulkan bahwa google trends dapat meningkatkan presisi prediksi terhadap tingkat penjualan real estate dalam jangka pendek. Collison (2019) menyatakan bahwa pemodelan statistik mengenai performa peramalan jumlah penjualan mobil "Ford" yang mengakomodir variable prediktor Google Trends lebih baik daripada model yang tidak mengakomodir. Kajian penggunaan Google Trends dalam sektor transportasi pernah dilakukan oleh Camacho (2017), dalam penelitiannya dibuktikkan juga bahwa penggunaan Google Trends dapat meningkatkan model yang terbentuk dalam memprediksi jumlah travellers yang mengunjungi Spanyol. Sedangkan penelitian terkait dengan peramalan jumlah penumpang kereta api di Indonesia, Katabba (2021) menggunakan model SARIMA $(0,1,1)$ $(2,1,1)^{12}$ dan Arianto $(2017)$ menggunakan model ARIMA Box-Jenkins $(1,1,12)$ dalam melakukan peramalan terhadap nilai aktual jumlah penumpang kereta api.

\section{METODE PENELITIAN}

\section{Data dan Sumber Data}

Terdapat dua (2) data utama yang digunakan dalam penelitian ini, yakni data official statistics jumlah penumpang kereta api dan indeks google trend (GT). Periode data yang digunakan adalah pada Januari 2016 s.d. Juli 2021. Periode data ini dipilih karena terdapatnya penyempurnaan sistem pengumpulan data indeks GT oleh Google yang berlaku sejak 1 Januari 2016, serta mempertimbangkan proses digitalisasi layanan PT.KAI yang dinilai mulai stabil dan dikenal oleh masyarakat luas pada periode tersebut.

Rincian sumber data dapat dijelaskan sebagai berikut:

1. Data Jumlah Penumpang Kereta Api yang digunakan sebagai variable respon/target peramalan $\left(\mathrm{Y}_{\mathrm{t}}\right)$ adalah data bulanan jumlah penumpang kereta api yang dihasilkan oleh Badan Pusat Statistik. Series data yang digunakan dalam pembuatan model statistik adalah total penumpang kereta api di Jawa dan Sumatera.

2. Indeks Google Trend (GT) yang digunakan sebagai variable bebas/nowcast $\left(\mathrm{X}_{\mathrm{t}}\right)$ pemodelan merupakan series indeks bulanan periode Januari 2016 hingga Juli 2021 dengan kata kunci yang diseleksi sehingga ditemukan series indeks GT yang memiliki korelasi tertinggi dengan variable respon $\left(\mathrm{Y}_{\mathrm{t}}\right)$. Data ini diperoleh dari web Google Trends. Selanjutnya, Indeks GT bulan Agustus 2021 digunakan untuk melakukan nowcasting terhadap jumlah penumpang kereta api periode tersebut. 


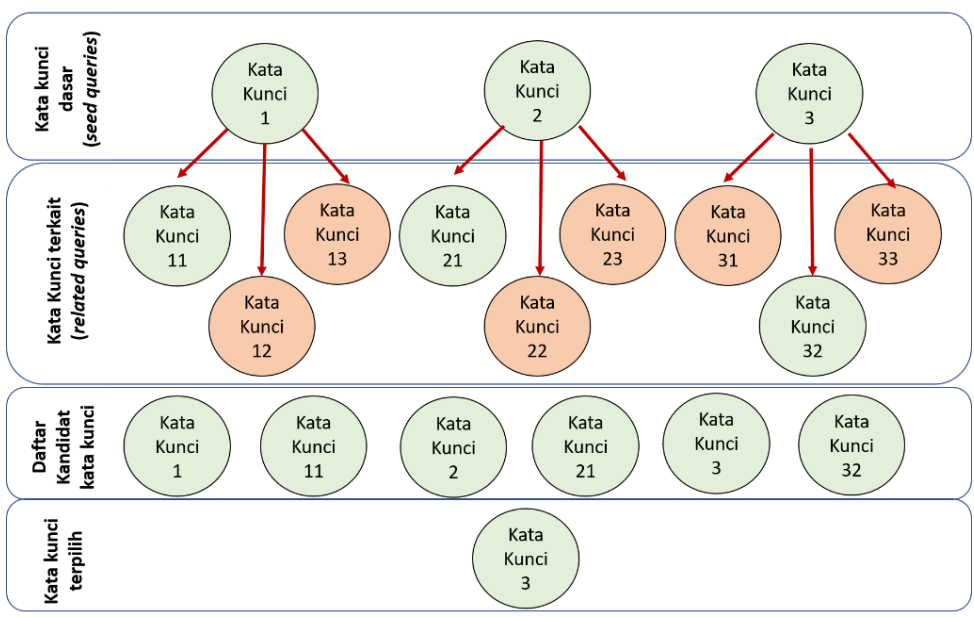

Gambar 1. Kerangka Kerja Pemilihan Kata Kunci Indeks Google Trends.

Kerangka kerja pemilihan kata kunci dibangun dengan mengkombinasikan metode pemilihan yang dilakukan oleh Mitra et, al (2017) dan Akbar (2019). Adapun tahapan pemilihan kata kunci sesuai kerangka kerja pemilihan kata kunci pada Gambar 1 di atas adalah sebagai berikut:

1. Menentukan daftar kata kunci pencarian dasar (seed queries). Kata kunci pencarian dasar ini merupakan kata kunci dasar yang dianggap relevan oleh peneliti terkait aktivitas yang berhubungan erat dengan penumpang kereta api.

2. Mengidentifikasi kata kunci pencarian terkait (related queries) dengan google correlate. Tahapan ini termasuk mengeliminasi kata kunci yang kurang relevan dengan variabel respon maupun menyeleksi kata kunci yang duplikat.

3. Menyusun kumpulan/list kata kunci yang relevan dan mengukur koefisien korelasi pearson masingmasing indeks GT dari kata kunci terpilih dengan variabel respon

4. Kata kunci yang memiliki koefisien korelasi tertinggi digunakan dalam analisis lanjut dengan pemodelan statistik.

\section{Metode analisis}

Pemodelan pada penelitian ini dilakukan dengan penentuan terlebih dahulu series data variabel bebas (exogenous variabel) dengan menyeleksi kata kunci pencarian yang tepat. Seleksi kata kunci didasari evaluasi series data terpilih dengan variabel respon menggunakan koefisien korelasi Pearson. Selanjutnya, penerapan pemodelan statistik dilakukan dengan metode Time Series Regression. Model ini dipilih karena dinilai mampu menangkap kedinamisan pada data time series yang seringkali dipengaruhi oleh lag pada waktu sebelumnya. Selain itu, sebagai benchmark perbandingan model, juga dilakukan pemodelan autoregressive yang mengakomodir pola musiman dan exogenous variabel dengan Seasonal Autoregressive Integrated Moving Average with Exogenous Variable (SARIMAX). Kedua metode ini nantinya dievaluasi dengan indikator tertentu untuk didapatkan model terbaik sebelum digunakan untuk proses nowcasting jumlah penumpang kereta api pada bulan Agustus tahun 2021.

\section{Koefisien Korelasi Pearson}

Analisis korelasi pearson digunakan untuk mengetahui kekuatan hubungan antara 2 (dua) variabel yang saling berhubungan. Penentuan besar pengaruh dapat dilakukan dengan penghitungan sebagai berikut: (Makridakis, 1993:194)

$r_{x y}=\frac{n \sum_{i=1}^{n} x_{i} y_{i}-\left(\sum_{i=1}^{n} x_{i}\right)\left(\sum_{i=1}^{n} y_{i}\right)}{\sqrt{\left\{n \sum_{i=1}^{n} x_{i}^{2}-\left(\sum_{i=1}^{n} x_{i}\right)^{2}\right\}-\left\{n \sum_{i=1}^{n} y_{i}^{2}-\left(\sum_{i=1}^{n} y_{i}\right)^{2}\right.}}$

dimana:

$r_{x y}=$ Koefisien korelasi pearson

$x_{i} \quad=$ Variabel bebas/prediktor

$y_{i} \quad=$ Variabel respon

$\mathrm{n} \quad=$ Jumlah sampel 


\section{Time Series Regression}

Analisis regresi merupakan suatu teknik analisis data yang digunakan untuk mengkaji dua atau lebih variabel yang berkaitan. Menurut Draper dan Smith (1998), regresi time series terdiri dari variabel dependen yang dipengaruhi oleh variabel independen yang telah diketahui.

$Y_{t}=\beta_{1} X_{1, t}+\beta_{1} X_{2, t}+\cdots+\beta_{k} X_{k, t}+\alpha_{t}$

dimana:

$Y_{t} \quad=$ variabel respon periode ke-t

$X_{k, t}=$ variabel bebas ke-k periode ke-t

$\beta_{k}=$ koefisien persamaan regresi variabel bebas ke-k

$\alpha_{t}=$ error terms

Koefisien persamaan regresi pada persamaan di atas diperoleh dari perhitungan sebagai berikut:

$\boldsymbol{\beta}=\left(\mathbf{X}^{\prime} \mathbf{X}\right)^{-1}\left(\mathbf{X}^{\prime} \mathbf{Y}\right)$

dengan

$\mathbf{X}=\left[\begin{array}{cccc}x_{11} & x_{12} & \cdots & x_{1 k} \\ x_{21} & x_{22} & \cdots & x_{2 k} \\ \vdots & \vdots & \ddots & \vdots \\ x_{n 1} & x_{n 2} & \cdots & x_{n k}\end{array}\right] \boldsymbol{\beta}=\left[\begin{array}{c}\beta_{1} \\ \beta_{2} \\ \vdots \\ \beta_{k}\end{array}\right] \boldsymbol{Y}=\left[\begin{array}{c}y_{1} \\ y_{2} \\ \vdots \\ y_{k}\end{array}\right]$

\section{SARIMAX}

Model Autoregressive Integrated Moving Average (ARIMA) merupakan salah satu model umum yang sering digunakan dalam model time series univariate. Model ARIMA yang mempertimbangkan efek musiman dikenal sebagai Seasonal Autoregressive Integrated Moving Average (SARIMA). Lebih lanjut, seringkali dalam suatu penelitian, peneliti memberikan penambahan variabel yang dianggap memiliki pengaruh nyata terhadap variabel respon sehingga dapat menambah akurasi dalam melakukan forecasting. Penambahan variabel tambahan sebagai prediktor (variabel exogenous) dalam model SARIMA dikenal sebagai model SARIMAX (Arunraj, et al., 2016). Bentuk umum SARIMA $(p, d, q)(P, D, Q)^{S}$ dengan modifikasi penambahan variable exogenous dapat ditulis sebagai berikut (Montgomery, et al., 2008):

$\phi^{*}\left(B^{s}\right) \phi(B)(1-B)^{d}\left(1-B^{S}\right)^{D} y_{t}=\delta+\beta_{1} X_{1, t}+\beta_{1} X_{2, t}+\cdots+\beta_{k} X_{k, t}+\Theta^{*}\left(B^{S}\right) \Theta(B) \epsilon_{t}$

dimana:

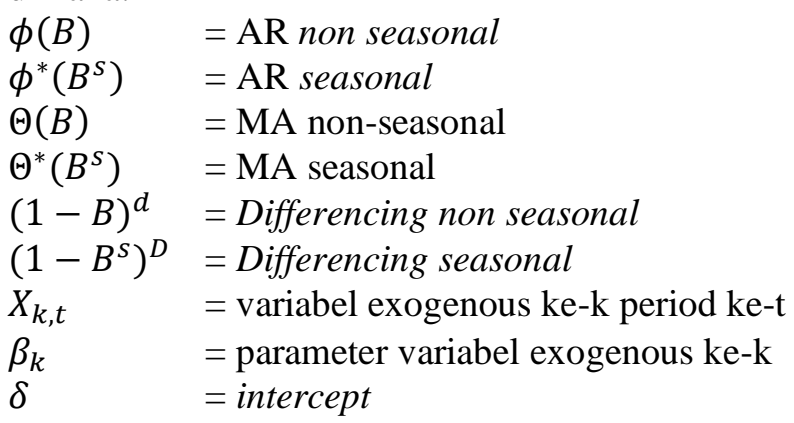

\section{Pemilihan model terbaik}

Pemilihan model terbaik dilakukan dengan melakukan evaluasi model melalui dua ukuran keakuratan, yakni Root Mean Square Error (RMSE) dan Mean Absolute Error (MAE). Menurut Hyndman dan Koehler (2006), RMSE sering digunakan sebagai metode evaluasi model karena dapat menyamakan skala dari data yang digunakan. Rumus RMSE dapat dituliskan sebagai berikut:

$R M S E=\sqrt{\frac{\sum_{t=1}^{n}\left(Y_{t}-\widehat{Y_{t}}\right)^{2}}{n}}$ 
dimana:

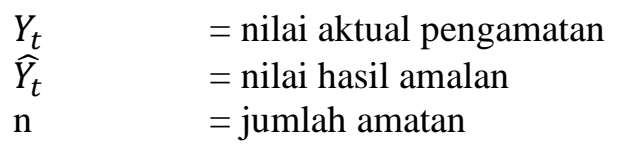

Mean Absolute Error (MAE) menyatakan rata-rata nilai absolut penyimpangan hasil peramalan terhadap nilai data aktual (Subagyo, 1986). MAE dapat digunakan untuk mengindikasikan seberapa layak sebuah model untuk digunakan dalam melakukan ramalan. Semakin kecil MAE sebuah model artinya semakin baik nilai ramalan yang dihasilkan dalam mendekati nilai aktual amatan.

$M A E=\frac{1}{n}\left|Y_{t}-\hat{Y}_{t}\right|$

dimana

$Y_{t} \quad=$ nilai aktual pengamatan

$\widehat{Y}_{t} \quad=$ nilai hasil ramalan

$\mathrm{n} \quad \quad=$ jumlah amatan

Hasil pemodelan dengan time series regression dan SARIMAX akan saling diperbandingkan. Model dengan dengan nilai RMSE dan MAE terkecil akan dipilih sebagai model terbaik yang akan digunakan nowcasting.

\section{HASIL DAN PEMBAHASAN}

\section{Kata Kunci Pencarian Dasar (Seed Queries)}

Kata kunci pencarian dasar adalah daftar kata kunci yang dianggap relevan oleh peneliti terkait dengan aktivitas perkeretaapian di Indonesia, sehingga nantinya dapat digunakan sebagai variabel tambahan dalam memprediksi jumlah penumpang kereta api. Peneliti menentukan sepuluh kata kunci pencarian dasar berdasarkan eksplorasi, pengamatan dan analisis peneliti terkait aktivitas perkeretaapian selama lima tahun terakhir. Sepuluh kata kunci dasar yang dianggap relevan dengan penumpang kereta api antara lain: "KAI Access", "stasiun", "tiket KAI", "stasiun kereta", "kereta api”, "tiket kereta KAI", "KAI”, "kereta", "jadwal kereta api", dan "rute kereta api".

\section{Kata Kunci Pencarian Terkait (Related Queries)}

Kata kunci pencarian dasar yang telah diperoleh kemudian diperluas cakupanya dengan google correlate, yakni kata kunci terkait (related queries) yang disarankan otomatis oleh Google terkait kata kunci dasar yang telah diinput sebelumnya. Daftar kata kunci yang dihasilkan pada proses ini adalah 60 kata kunci terkait. Proses ini sekaligus melengkapi daftar kata kunci dasar sebelumnya yang kemudian akan dianalisis kaitanya dengan variabel respon jumlah penumpang kereta api.

\section{Seleksi Kata Kunci}

Kata kunci pencarian dasar (seed queries) dan terkait (related queries) diseleksi dengan metode analisis korelasi pearson. Berikut daftar lima kata kunci pencarian yang memiliki koefisien korelasi tertinggi dengan variabel respon.

Tabel 1. Kata kunci pencarian yang berkorelasi kuat dengan jumlah penumpang kereta api.

\begin{tabular}{cc}
\hline Kata Kunci Pencarian & Koefisien Korelasi Pearson \\
\hline kereta & 0,914 \\
tiket kereta api & 0,865 \\
tiket kereta & 0,848 \\
KAI access & 0,844 \\
jadwal kereta & 0,839 \\
\hline
\end{tabular}

Dari tabel di atas diketahui bahwa kata kunci pencarian yang memiliki korelasi terkuat dengan variabel respon adalah "kereta". Selanjutnya, series data indeks GT yang berasal dari kata kunci ini akan digunakan sebagai variabel prediktor dalam pemodelan statistik jumlah penumpang kereta api. 


\section{Gambaran Umum Indeks Google Trends "Kereta” dan Jumlah Penumpang Kereta Api}

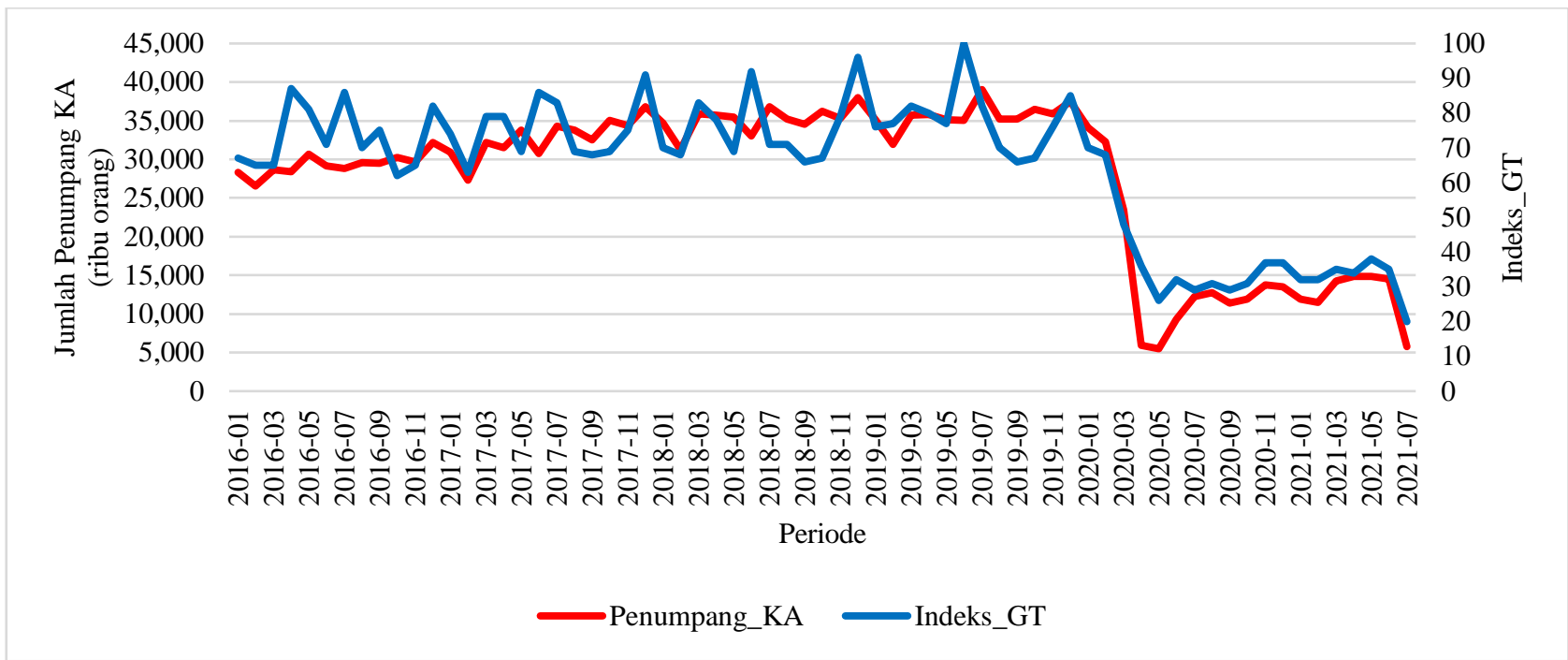

Sumber: BPS dan Web Google Trends (https://trends.google.com) (data diolah)

Gambar 2. Pergerakan Data Jumlah Penumpang Kereta Api dan Indeks Google Trends Periode 2016-2021.

Plot data runtun waktu pada Gambar 1 menunjukkan secara umum pola sebaran data indeks google trends dan jumlah penumpang kereta api yang dirilis oleh BPS setiap bulan menunjukkan kesamaan pola arah sebaran. Selain nilai koefisien korelasi pearson yang memiliki hubungan kuat, pola sebaran yang searah ini menguatkan dugaan bahwa indeks Google Trends yang datanya cenderung tersedia lebih cepat mampu untuk menggambarkan kondisi indikator jumlah penumpang kereta api yang mana rilis datanya membutuhkan jeda waktu.

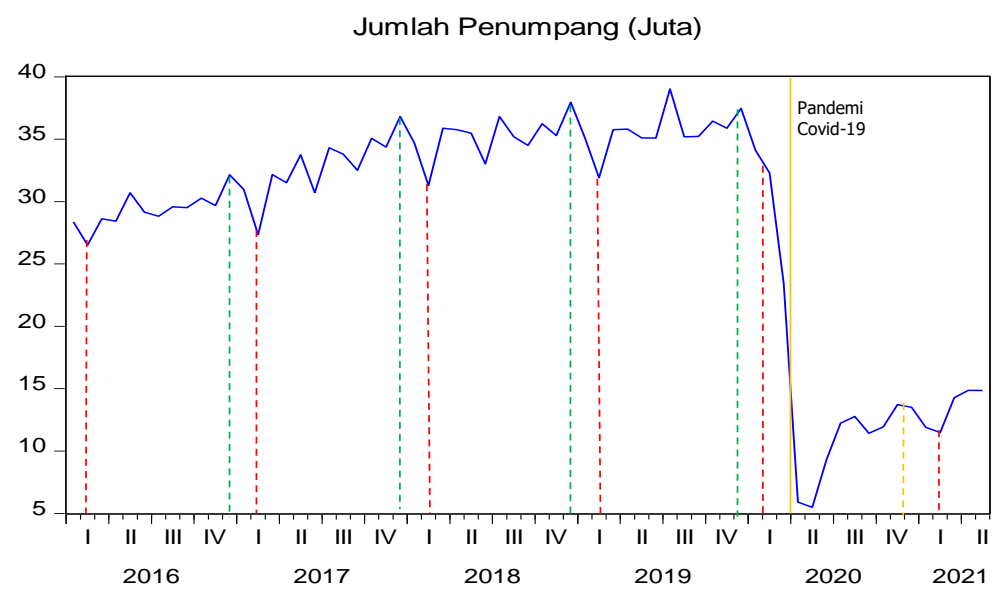

Gambar 3. Pola Seasonal Bulanan Jumlah Penumpang Kereta Api Periode 2016-2021.

Dari Gambar 2 di atas dapat diketahui bahwa tren jumlah penumpang kereta api mengalami pola musiman bulanan, dimana puncak jumlah penumpang tertinggi di setiap tahun biasanya terjadi pada libur akhir tahun sekitar bulan Desember dan terendah pada bulan Februari-Maret. Fenomena ini mengindikasikan bahwa nilai variabel pada tahun lalu (t-12) menjadi gambaran penting terhadap kenaikan/penurunan variabel pada periode berjalan. Hal ini menjadi perhatian peneliti sebagai salah satu faktor yang harus dipertimbangkan dalam penyusunan model statistik baik dengan time series regression maupun SARIMAX.

\section{Pemodelan dengan Time Series Regression}

Pemodelan dengan time series regression menggunakan beberapa kombinasi antara variabel respon Jumlah penumpang kereta api dan variabel bebas sebagai berikut:

\section{Model 1:}

Dibangun dengan menggunakan data jumlah penumpang kereta api pada bulan sebelumnya (t-1) dan dengan efek musiman (t-12) sebagai variabel bebas. 
$\log \left(\right.$ PenumpangK $\left.A_{t}\right)=\beta_{0}+\beta_{1} * \log \left(\right.$ PenumpangK $\left.A_{t-1}\right)+\beta_{2} * \log \left(\right.$ Penumpang $\left.K A_{t-12}\right)+\varepsilon_{t}$

Tabel 2. Persamaan satu model jumlah penumpang kereta api dengan time series regression

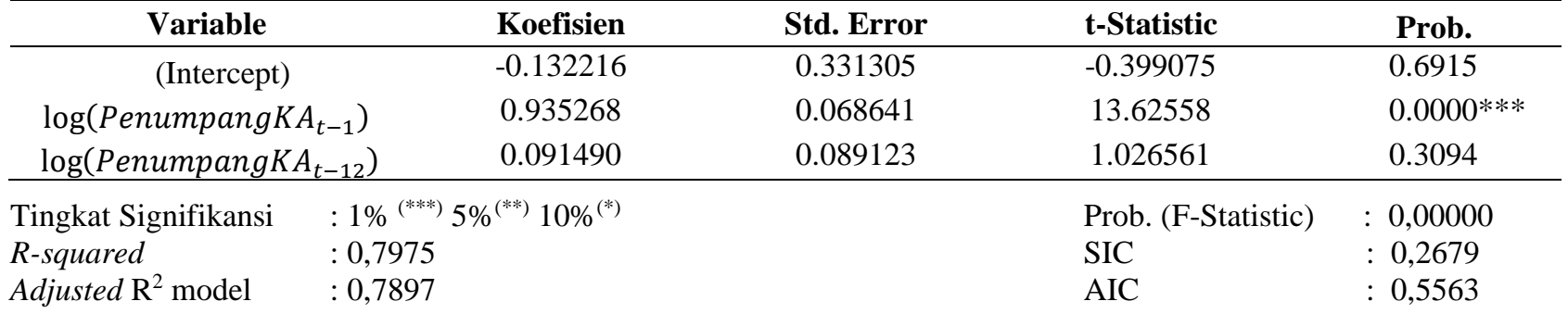

Persamaan time series regression yang dihasilkan dengan model ini dapat dituliskan sebagai berikut:

$\log \left(\right.$ Penumpang $\left.K A_{t}\right)=-0,1322+0,9352 * \log \left(\right.$ Penumpang $\left.K A_{t-1}\right)-0,0915 *$ $\log \left(\right.$ PenumpangK $\left.A_{t-12}\right)+\varepsilon_{t}$

\section{Model 2:}

Dibangun dengan menggunakan data indeks Google Trends pada bulan berjalan ( $\mathrm{t}$ ) dan dengan efek musiman (t-12) sebagai variabel bebas.

$\log \left(\right.$ PenumpangK $\left.A_{t}\right)=\beta_{0}+\beta_{1} * \log \left(G T_{t}\right)+\beta_{2} * \log \left(G T_{t-12}\right)+\varepsilon_{t}$

Tabel 3. Persamaan dua model jumlah penumpang kereta api dengan time series regression

\begin{tabular}{|c|c|c|c|c|}
\hline Variable & Koefisien & Std. Error & t-Statistic & Prob. \\
\hline (Intercept) & -1.255906 & 0.399579 & -3.143077 & $0.0028 * * *$ \\
\hline $\log \left(G T_{t}\right)$ & 1.322434 & 0.066213 & 19.97247 & $0.0000 * * *$ \\
\hline $\log \left(G T_{t-12}\right)$ & -0.217282 & 0.103623 & -2.096852 & $0.0409 * *$ \\
\hline Tingkat Signifikansi & $: 1 \%{ }^{(* * *)} 5 \%^{(* *)} 10 \%^{(*)}$ & & Prob. (F-Statistic) & $: 0,00000$ \\
\hline $\begin{array}{l}\text { R-squared } \\
\text { Adiusted } \mathrm{R}^{2} \text { model }\end{array}$ & $\begin{array}{l}: 0,8982 \\
: 0,8942\end{array}$ & & $\begin{array}{l}\text { SIC } \\
\text { AIC }\end{array}$ & $\begin{array}{l}:-0.4192 \\
:-0.5287\end{array}$ \\
\hline
\end{tabular}

Persamaan time series regression yang dihasilkan dengan model ini dapat dituliskan sebagai berikut:

$\log \left(\right.$ PenumpangK $\left.A_{t}\right)=-1,256+1,322 * \log \left(G T_{t}\right)-0,2172 * \log \left(G T_{t-12}\right)+\varepsilon_{t} \ldots$

\section{Model 3:}

Dibangun dengan menggunakan data indeks Google Trends pada bulan berjalan (t) dan efek musiman (t-12) serta data jumlah penumpang kereta api pada bulan sebelumnya (t-1) dan efek musiman ( $\mathrm{t}-12)$ sebagai variabel bebas.

$\log \left(\right.$ PenumpangK $\left.A_{t}\right)=\beta_{0}+\beta_{1} * \log \left(G T_{t}\right)+\beta_{2} * \log \left(G T_{t-12}\right)+\beta_{3} * \log \left({\left.\text { Penumpang } K A_{t-1}\right)+}\right)+$ $\beta_{4} * \log \left(\right.$ PenumpangK $\left.A_{t-12}\right)+\varepsilon_{t}$

Tabel 4. Persamaan tiga model jumlah penumpang kereta api dengan time series regression

\begin{tabular}{ccccc}
\hline Variable & Koefisien & Std. Error & t-Statistic & Prob. \\
\hline (Intercept) & -0.794139 & 0.480413 & -1.653032 & 0.1046 \\
$\log (\mathrm{GT})$ & 1.197054 & 0.167151 & 7.161528 & $0.0000^{* * *}$ \\
$\log (\mathrm{GT}(-12))$ & -0.458367 & 0.234374 & -1.955709 & $0.0561^{*}$ \\
$\log ($ PenumpangKA(-1)) & 0.116467 & 0.121958 & 0.954972 & 0.3442 \\
$\log ($ PenumpangKA(-12)) & 0.205004 & 0.137663 & 1.489175 & 0.1427 \\
\hline Tingkat Signifikansi $\quad: 1 \%{ }^{(* *)} 5 \% \%^{(* *)} 10 \%{ }^{(*)}$ & & Prob. (F-Statistic) & $: 0,00000$ \\
R-squared & $: 0,9076$ & & SIC & $:-0,3711$ \\
Adjusted $\mathrm{R}^{2}$ model $\quad: 0,9003$ & & AIC & $:-0,5536$
\end{tabular}

Persamaan time series regression yang dihasilkan dengan model ini dapat dituliskan sebagai berikut:

$\log \left(\right.$ PenumpangK $\left.A_{t}\right)=-0,7941+1,1970 * \log \left(G T_{t}\right)-0,4583 * \log \left(G T_{t-12}\right)+0,1165 *$ $\log \left(\right.$ PenumpangK $\left.A_{t-1}\right)+0,2050 * \log \left(\right.$ PenumpangK $\left.A_{t-12}\right)+\varepsilon_{t}$ 


\section{Pemodelan dengan SARIMAX}

Pemodelan dengan SARIMAX dilakukan dengan menambahkan variabel indeks Google Trends ke dalam model SARIMA. Pembentukan model SARIMA diawali dengan mencermati pola ACF dan PACF pada variabel jumlah penumpang kereta api.

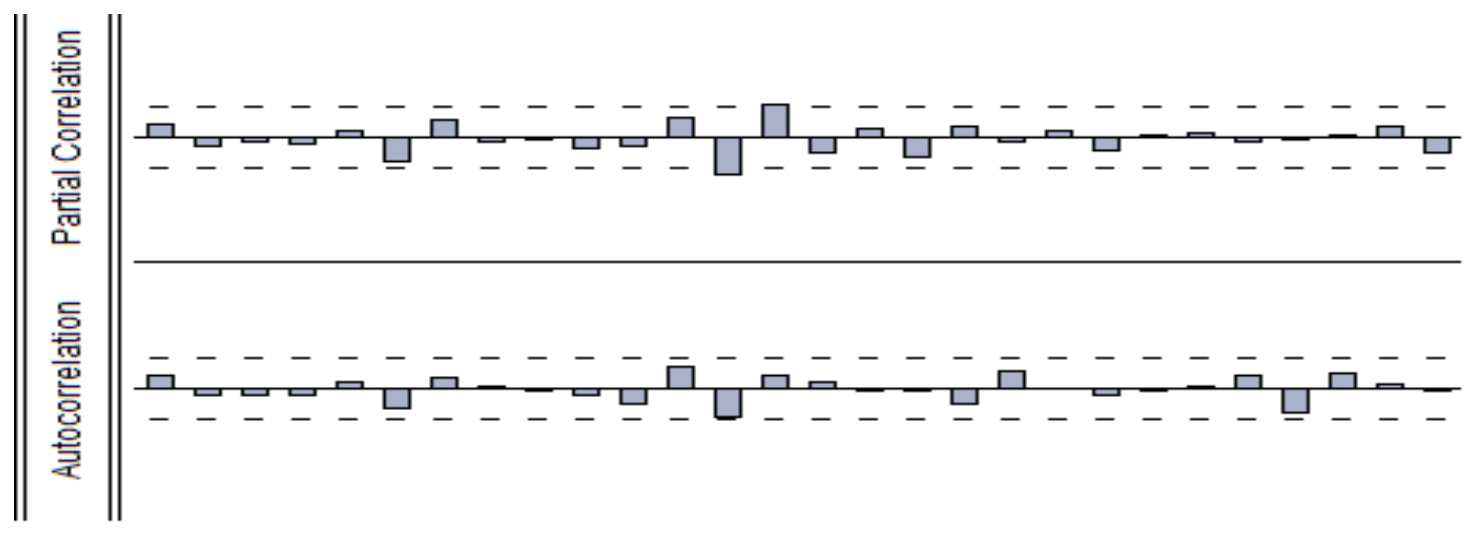

Gambar 4. Plot ACF dan PACF jumlah penumpang kereta api pada $1^{\text {st }}$ level

Berdasarkan Gambar 3, dengan pola ACF dan PACF yang sejalan, yakni signifikan di lag 1 dan mengalami cut-off di lag selanjutnya merupakan indikasi model AR (1) dan MA (1). Selain itu, terdapat plot seasonal pada lag kelipatan 12 sehingga membentuk plot seasonal SAR (12). Dengan mempertimbangkan pola ACF dan PACF di atas serta tingkat stationeritas data, maka model SARIMA yang digunakan yakni SARIMA $(1,1,1)(1,1,0)^{12}$.

Tabel 5. Persamaan model SARIMAX

\begin{tabular}{ccccc}
\hline Variable & Koefisien & Std. Error & t-Statistic & Prob. \\
\hline (Intercept) & 0.002086 & 0.003295 & 0.633087 & 0.5291 \\
$\mathrm{~d}(\log (\mathrm{GT})$ & 1.279755 & 0.109903 & 11.64435 & $0.0000^{* * *}$ \\
$\mathrm{AR}(1)$ & 0.230997 & 0.134318 & 1.719785 & $0.0906^{*}$ \\
$\mathrm{SAR}(12)$ & 0.232133 & 0.116265 & 1.996575 & $0.0504^{*}$ \\
MA(1) & -1.000000 & 1042.455 & -0.000959 & 0.9992 \\
\hline Tingkat Signifikansi $\quad: 1 \%^{(* *)} 5 \%^{(* *)} 10 \%^{(*)}$ & & Prob. (F-Statistic) & $: 0,00000$ \\
R-squared & $: 0,4624$ & & SIC & $:-0,2705$ \\
Adjusted R $\mathrm{R}^{2}$ model & $: 0,4176$ & & AIC & $:-0,4695$
\end{tabular}

Berdasarkan tabel 5 di atas, persamaan SARIMAX $(1,1,1)(1,1,0)^{12}$ dapat dituliskan sebagai berikut:

$\phi^{*}\left(B^{s}\right) \phi(B)(1-B)^{d}\left(1-B^{s}\right)^{D} y_{t}=\delta+\beta_{1} X_{1, t}+\beta_{1} X_{2, t}+\cdots+\beta_{k} X_{k, t}+\Theta^{*}\left(B^{s}\right) \Theta(B) \epsilon_{t}$

dengan memasukkan hasil estimasi parameter didapatkan

$\left(1-0,2321 B^{12}\right)(1+0,2309 B)(1-(1-B))^{1}\left(1-\left(1-B^{12}\right)\right)^{1} y_{t}=-0,0021+1,2797 * \log (G T)+(1+B) \epsilon_{t}$

Jika dijabarkan menjadi

$y_{t}=\frac{-0,0021+1,2797 * \log (G T)+(1+B)}{\left(1-0,2321 B^{12}\right)(1+0,2309 B)(B)^{1}\left(B^{12}\right)^{1}}+\epsilon_{t}$

$y_{t}=\frac{-0,0021+1,2797 * \log (G T)+\left(1+y_{t-1}\right)}{\left(1-0,2321 y_{t-12}\right)\left(1+0,2309 y_{t-1}\right)\left(y_{t-1}\right)\left(y_{t-12}\right)}+\epsilon_{t}$

\section{Perbandingan Model Time Series Regression dengan Metode SARIMAX}

Setelah dilakukan pemodelan dengan time series regression dan SARIMAX, maka langkah selanjutnya adalah memilih model terbaik yang akan digunakan dalam proses nowcasting. Pemilihan model ini mempertimbangkan indikator kesesuaian model, antara lain nilai adjusted $r$-squared, nilai F-Statistics, AIC, dan SIC. Selain itu, pemilihan model juga melihat indikator akurasi model dalam melakukan peramalan, yakni dengan nilai RMSE, MAE serta kesesuaian dari uji diagnostik residual white noise. 
Tabel 6. Perbandingan Keakuratan Peramalan Metode Analisis

\begin{tabular}{ccccccc}
\hline Model & Adj R $^{\mathbf{2}}$ & AIC & SIC & RMSE & MAE & White Noise \\
\hline Regresi $\left(\mathrm{y} \sim \mathrm{y}_{\mathrm{t}-1}+\mathrm{y}_{\mathrm{t}-12}\right)$ & 0,7897 & 0,5563 & 0,2679 & 15,30 & 13,17 & Ya \\
Regresi $\left(\mathrm{y} \sim \mathrm{x}_{\mathrm{t}-12}\right)$ & 0,8942 & -0.5287 & $-0,4192$ & 4,13 & 3,12 & Ya \\
Regresi $\left(\mathbf{y} \sim \mathbf{x}+\mathbf{x}_{\mathbf{t}-12}+\mathbf{y}_{\mathbf{t}-1}+\mathbf{y}_{\mathbf{t}-12}\right)$ & $\mathbf{0 , 9 0 0 3}$ & $\mathbf{- 0 , 5 5 3 6}$ & $\mathbf{- 0 , 3 7 1 1}$ & $\mathbf{3 , 6 9}$ & $\mathbf{2 , 8 4}$ & Ya \\
SARIMAX $(1,1,1)(1,1,0)^{12}$ & 0,4176 & $-0,4695$ & $-0,2705$ & 4,36 & 3,31 & Ya \\
\hline
\end{tabular}

Tabel 6 di atas menampilkan perbandingan akurasi antar metode analisis. Dapat diketahui dari tabel tersebut bahwa model yang mengandung Indeks Google Trends sebagai variabel bebas secara umum memiliki akurasi lebih baik daripada model yang tidak menyertakan pada sampel amatan yang sama. Temuan ini sejalan dengan penelitian yang dilakukan oleh D'Amuri (2012) bahwa penambahan variabel Google Trends dalam data time series dapat meningkatkan efisiensi model yang ditunjukkan dengan penurunan Mean Square Error dalam melakukan peramalan.

Dari ukuran-ukuran keakuratan yang digunakan di atas, dapat terlihat bahwa model ketiga memiliki nilai RMSE dan MAE terkecil dibandingkan dengan tiga model lainnya, yang artinya secara relatif model ketiga memiliki akurasi peramalan paling baik. Selain itu model ketiga juga telah memenuhi asumsi white noise, yang artinya residual telah homogen dan tidak membentuk pola tertentu sehingga telah cocok untuk digunakan dalam proses peramalan. Dengan demikian, peneliti akan menggunakan model ketiga untuk melakukan nowcasting terhadap jumlah penumpang kereta api pada Agustus tahun 2021.

\section{Pendugaan Jumlah Penumpang Kereta Api}

Sebelum digunakan untuk proses peramalan, perlu diketahui terlebih dahulu apakah model yang dibentuk sudah cukup baik dan layak untuk tahap peramalan. Perbandingan antara data riil dengan data hasil prediksi model diperlukan untuk mengetahui seberapa tepat model terpilih mampu mendekati nilai data aktual.

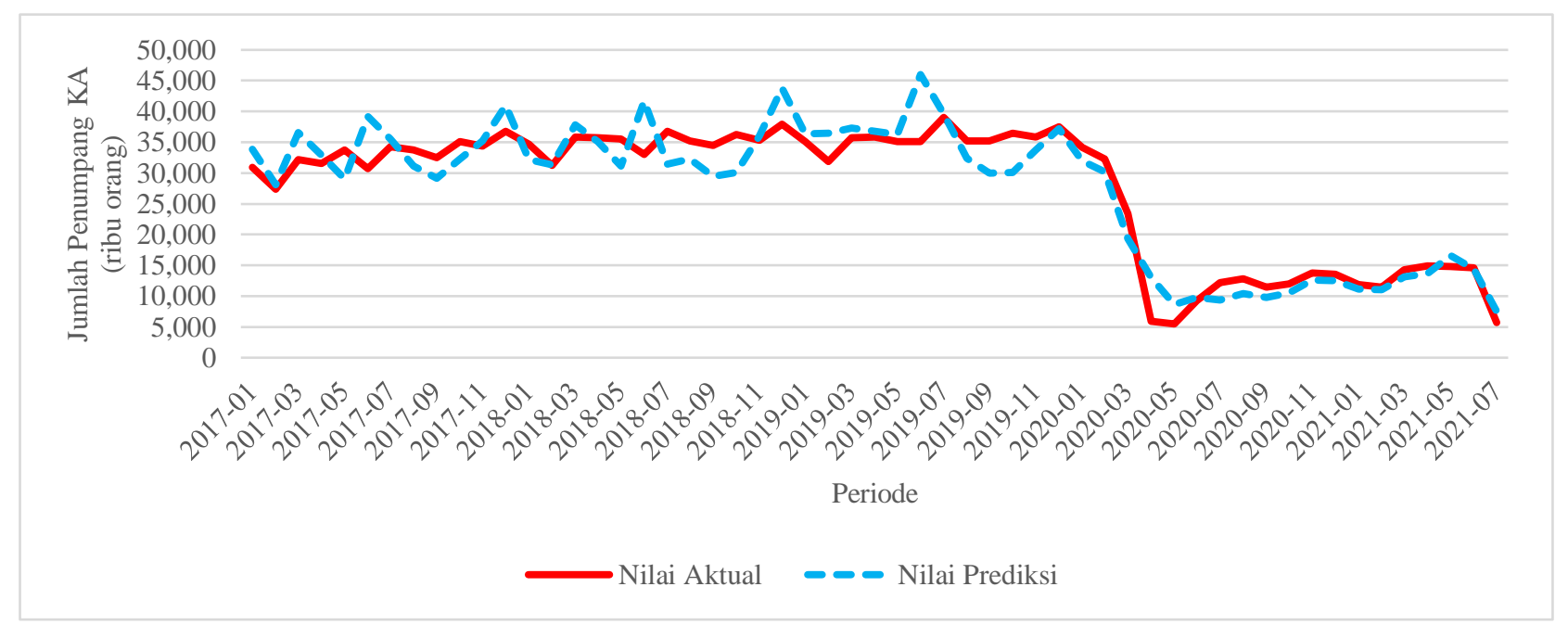

Gambar 5. Perbandingan nilai data aktual dan hasil prediksi jumlah penumpang kereta api 2017-2021.

Hasil perbandingan ini dapat dilihat pada Gambar 5 di atas. Terlihat pada Gambar tersebut bahwa kedua garis saling berdekatan, yang artinya model yang dihasilkan mampu meramalkan kondisi aktual jumlah penumpang kereta api dengan kondisi yang tidak jauh berbeda. Dengan ini dapat disimpulkan bahwa model telah cukup layak untuk digunakan dalam proses peramalan (nowcasting).

Tabel 7. Hasil nowcasting jumlah penumpang kereta api bulan Agustus 2021 (ribu orang).

\begin{tabular}{cccc}
\hline Periode & Nilai Prediksi & $\boldsymbol{\%} \boldsymbol{y}$-o-y & \% $\boldsymbol{m}$ - $\boldsymbol{t}$ - $\boldsymbol{m}$ \\
\hline Agustus 2021 & 9.027 & $-29,33 \%$ & $57,07 \%$ \\
\hline
\end{tabular}

Hasil nowcasting jumlah penumpang kereta api ditunjukkan pada Tabel 7. Prediksi jumlah penumpang kereta api pada bulan Agustus 2021 adalah sebesar 9,03 juta orang. Angka ini menurun -29,33\% y-o-y dari Agustus tahun 2020. Sedangkan secara $m$-t- $m$, yakni dengan periode Juli 2021 maka angka tersebut meningkat sebesar 57,07\%. Terjadinya kenaikan jika dilihat secara $m-t-m$ dikarenakan lower base effect dimana pada periode sebelumnya terdapat Pemberlakuan Pembatasan Kegiatan Masyarakat (PPKM) darurat di Jawa-Bali pada periode 3 Juli-20 Agustus 2021 dan PPKM Level 4 periode 21 Juli-2 Agustus 2021 yang membatasi dengan ketat mobilitas masyarakat melalui kereta api sehingga pada bulan tersebut (Juli 2021) jumlah 
penumpang kereta api turun drastis menjadi 5,75 juta orang. Selain itu, trend kenaikan pada bulan Agustus 2021 dibandingkan bulan sebelumnya dikarenakan terdapatnya beberapa pelonggaran pada persyaratan bepergian dengan KA dan kasus Covid-19 yang sudah lebih baik dari periode Juli 2021, sehingga meningkatkan kepercayaan masyarakat untuk melakukan mobilitas dengan moda transportasi ini.

\section{KESIMPULAN}

Pada penelitian ini ditunjukkan bahwa pengunaan Indeks google trends dapat digunakan untuk membentuk model jumlah penumpang kereta api, hal ini didasari oleh pergerakan kedua variabel dari waktu ke waktu yang memiliki kesamaan pola dan arah. Mengingat ketersediaan data indeks google trends yang cenderung lebih cepat dari official statistics yang dirilis oleh BPS, pemanfaatan indeks google trends dapat digunakan sebagai sumber data alternatif untuk melakukan nowcasting terhadap jumlah penumpang kereta api. Berdasarkan hasil penelitian juga dapat dibuktikan bahwa penggunaan indeks google trends dalam model time series mampu meningkatkan tingkat akurasi peramalan model. Pada model time series regression yang telah dibentuk, diprediksi jumlah penumpang kereta api pada Agustus 2021 adalah sebesar 9,03 juta orang. Trend jumlah penumpang yang cenderung meningkat secara $m-t-m$ dikarenakan terdapatnya pelonggaran pada mobilitas masyarakat dan kasus Covid-19 yang lebih terkendali dibandingkan periode Juli 2021, sehingga mampu meningkatkan kepercayaan masyarakat dalam melakukan mobilisasi dengan moda transportasi ini.

\section{DAFTAR PUSTAKA}

[APJII] Asosiasi Penyelenggara Jasa Internet Indonesia .(2020). Survei Pengguna Internet di Indonesia 2019Q2 2020. Buletin APJII. Edisi 74.

Arianto, B.W. (2017). Peramalan Jumlah Penumpang Kereta Api di Pulau Jawa dan Sumatera Menggunakan Metode Arima Box-Jenkins. Tesis Institut Teknologi Sepuluh November. Surabaya. $64 \mathrm{hlm}$.

Arunraj, N., Ahrens, D., and Fernandes, M. (2016). Application of SARIMAX Model to forecast Daily Sales in Food Retail Industry. International Journal of Operation Research and Information Systems.7(1), 1-21.

Akbar, Ilmi Aulia. \& Kurniawan, R. (2019). Pemodelan Nowcasting Tingkat Pengangguran Terbuka Menggunakan Data Google Trends dengan Metode Antlion Optimization-Support Vector Regression. Prosiding Seminar Nasional Official Statistics 2019. Badan Pusat Statistik.

Ayuningtyas, I., \& Wirawati, I. (2019). Nowcasting Tingkat Penghunian Kamar Hotel Menggunakan Google Trends. Prosiding Seminar Nasional Official Statistics 2019. Badan Pusat Statistik.

Camacho, Maximo. \& Pacce, Jose Matias. (2017). Forecasting Travellers In Spains With Google's Search Volume Indices. SAGE Journals.

Choi, H., and Varian, H. (2012). Predicting the present with Google trends, Economic Record, 88(1), Issue s1, pages 2-9.

Collison, J.A. (2019). Performance Assesment of Google Index in Forecasting Car Sales in Argetina. Universidad de Buenos Aires. Argentina.

D'Amuri, Francesco and Marcucci, Juri, (2012), The predictive power of Google searches in forecasting unemployment, No 891, Temi di discussione (Economic working papers), Bank of Italy, Economic Research and International Relations Area.

Draper, N. R., \& Smith, H. (1998). Applied Regression Analysis (3rd ed.). Canada: John Willey \& Sons, Inc.

Hyndman, R.J., \& Koehler, A.B. (2006). Another Look at Measures of Forecast Accuracy. International Journal of Forecasting, 679-688.

Katabba, Y.I. (2021). Metode Seasonal Autoregressive Integrated Moving Average (SARIMA) untuk memprediksi Jumlah Penumpang Kereta Api di Pulau Sumatra. Skripsi Universitas Jambi. 83 hlm.

Makridakis, S., S. Wheelwright, R. Hyndman, and Y. Chang. (1998). Forecasting Methods and Applications. 3rd ed. New York: John Wiley \& Sons.

Mitra, P., Anirban, S., and Sohini, C. (2017). Nowcasting Real Estate Activity In India Using Google Trend Data. Reserve Bank of India Occasional Papers, Vol.38 No. 1\&2, 2017.

Montgomerry, et al. (2008). Introduction to Time Series Analysis and Forecasting. Amerika: John Wiley \& Sons Inc.

Subagyo, Pangestu. (1986). Forecasting Konsep dan Aplikasi. Yogyakarta: BPPE UGM. 